\title{
Critical Discourse Analysis of Community Reports on Public Complaints Information Systems LAPOR! (lapor.go.id)
}

\author{
Praditya Mer Hananto ${ }^{1}$, Arief Hartanto ${ }^{2}$, Yoka Pramadi ${ }^{3}$, Ubaidillah $^{4}$ and Al Araf \\ Assadallah Marzuki ${ }^{5}$ \\ \{battle_signal@yahoo.com¹, arie038@lipi.go.id², yoka001@lipi.go.id ${ }^{3}$, ubai001@lipi.go.id ${ }^{4}$, \\ alar001@lipi.go.id $\left.{ }^{5}\right\}$ \\ Doctoral Program Student at Faculty of Social and Political Sciences, University of Indonesia, Depok, \\ Indonesia ${ }^{1}$ \\ Research Center for Society and Culture, Indonesian Institute of Sciences, Jakarta, Indonesia $2,3,4,5$
}

\begin{abstract}
This article analyzes the report discourse submitted by the public on LAPOR! site. The analysis is directed at revealing the construction of the reporter's/community's perspective in viewing the people's-government relations. The construction of the perspective or ideology is reflected in the pattern of language use in the discourse of the report. Critical discourse analysis is used as a theory as well as a method for achieving that goal. Analysis shows that there is a shift in hierarchy in the psychological reality of the reporter. Reporting parties no longer see the government-people relations as patronclient. The reporters actually show that they feel in a condition that they have the right to be served ideally by the government. However, the trauma of the potential coercive treatment of the government that has occurred in the past makes a demonstration of the reporter authority's only if it is in anonymity condition.
\end{abstract}

Keywords: Critical Discourse Analysis, Information Systems, Public Complaints, LAPOR!

\section{Introduction}

The relationships that are formed and maintained between the government and the people seem to be established in a patron-client manner. The people are in a subordinate position which must be surrendered in the government's narrative. This pattern of relations may still be a product of the history of colonialism that Indonesian people have experienced. The hierarchical scheme is maintained until it influences the pattern of post-independence Indonesian relations.

Along with increasing awareness of the citizenship of the Indonesian people over their rights as citizens in the post-Reformation period, there has been an adaptation process undertaken by the government to change the pattern of patron-client relations through the Bureaucracy Reform which focuses on improving the quality of public services.

One form of such improvement is to increase the capacity of controlling public services through strengthening the monitoring and evaluation of public services, strengthening the service complaints system, as well as transparency and follow-up on public service issues. 
Utilization of communication technology was also carried out by presenting the portal lapor.go.id which was able to reach all elements of government both ministries, service offices in cities and districts, even state-owned enterprises. This portal is initiated by the president's staff office, Kemenpan RB, and the Ombudsman.

This article analyzes the report discourse submitted by the public on the LAPOR! Portal. The analysis is directed at revealing the construction of the reporter's/community's perspective in viewing the people's-government relations. The construction of the perspective or ideology is reflected in the pattern of language use in the discourse of the report. Critical discourse analysis is used as a theory as well as a method for achieving that goal.

LAPOR! services are representative of Article 19 paragraph (4) and paragraph (5) of Presidential Regulation Number 76 of 2013 concerning Management of Public Service Complaints that aims to provide a more effective means of complaints without having to come directly to the public service office, which then gives birth to a basis the law for the formation of LAPOR! services as stipulated in the Regulation of the Minister of Administrative Reform and Bureaucratic Reform of the Republic of Indonesia Number 3 of 2015 Regarding Road Map for the Development of a National Public Service Complaints Management System. The formation of this service is expected to provide the widest possible access to the public to be able to submit complaints about the services provided by the organizer. With the widest possible access, the public can participate more actively in encouraging the realization of excellent public services.

For the realization of excellent public services, LAPOR is only a forum to convey the aspirations of the public regarding their complaints or input on the conditions of public services that are integrated with government ministries/institutions by making a disposition of reports to relevant agencies, but reports that are made do not necessarily get services that are fast in the sense of not in accordance with the rules regarding reporting must be processed within 5 days.

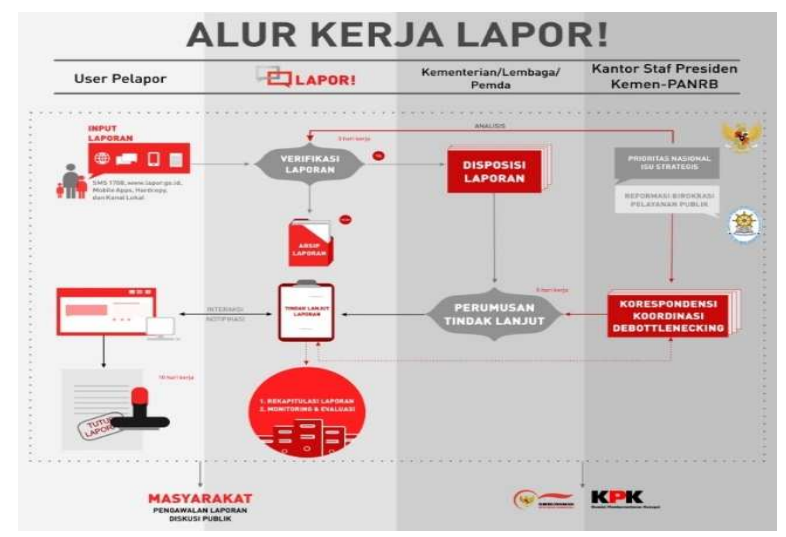

Fig 1. LAPOR! Workflow

Broadly speaking in the workflow online complaint system LAPOR! There are 4 main actors who carry out the reporting process and follow up on the report. The first one is, of course, there must be a reporter who is required to enter the portal on the website lapor.go.id site. Actually, it is not required to create a user account because of LAPOR! Has an 
anonymous feature. With this feature, one can report any event without logging in using an account. With notes, his name will be disguised.

The second actor is the administrator/verifier who is in charge of verifying the type of report and then disseminating it to the relevant agencies (ministries/institutions/local governments). Reports that have been distributed require follow-up from other key roles, namely Ministries, Institutions and Local Governments. If the report from the community is something of a national priority or strategic issue then the role of the Presidential Staff Office or the PANRB Ministry appears. Whereas the Corruption Eradication Commission (KPK) and the Ombudsman and the Indonesian people are the watchdogs and the guardians of public discussion reports.

LAPOR! Features consist of :

- Tracking ID LAPOR! .Tracking ID LAPOR! is a unique code that automatically completes every report published on the LAPOR! site. Tracking IDs can be used by users to search for a report.

- Anonymous and Confidential. Anonymous features are available for reporters to keep their identities confidential, while confidential features can be used to restrict access to reports only to reporters and reported agencies. Both of these features can be used for reporting sensitive and very private issues.

- Maps and Categorization. Each report can be labeled with a geographical location, topic, report completeness status, and related institutions so that the government and the public can monitor issues at various scales and perspectives. Map LAPOR! used as a flood information center at the time of Jakarta's major floods in 2012 and 2014 as a reference for the distribution of aid to victims.

- Policy Opinion. This feature can be used by government agencies that are connected as a means of public opinion polling. Some of the polls that have been carried out through this feature include the Health Social Security Agency and the 2013 New Curriculum Education Implementation Plan.

\section{Research Methods}

By using a critical approach to reporting texts in LAPOR! using critical discourse analysis, this study tries to find the realities that actually occur over existing reports. According to the understanding of Critical Discourse Analysis (CDA), text is not something that is free of value and describes reality as it really is.

Discourse, and any specific instance of discursive practice, is seen as simultaneously (i) a language text, spoken or written, (ii) discourse practice (text production and text interpretation), (iii) sociocultural practice. Furthermore, a piece of discourse is embedded within sociocultural practice at a number of levels: in the immediate situation, in the wider institution or organization, and at a societal level [1]. 


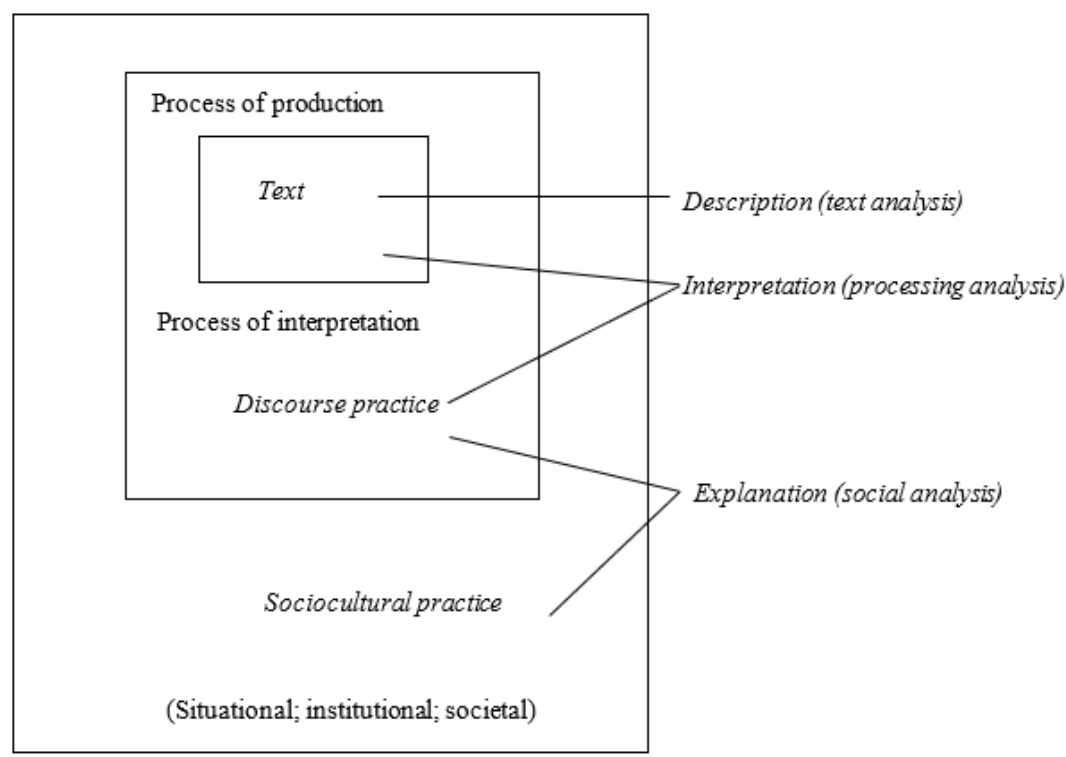

Dimensions of discourse

Dimensions of discourse analysis

Fig 2. Fairclough's three-dimensional framework for analysis of discourse

The method of discourse analysis includes linguistic description of the language text, interpretation of the relationship between the (productive and interpretative) discursive processes and the text, and explanation of the relationship between the discursive processes and the social processes [1].

There are several important characteristics of the critical discourse analysis presented by Fauzan [2] extracted from the writings of Fairclough [1] and and Eriyanto [3]. The first important character is Action. In his understanding, discourse is socialized as a form of interaction. Discourse is not seated as in a closed room and only applies internally. In the character of this action, discourse is seen as something that has a purpose (can influence others, debate, persuade, refute, motivate, react, forbid, etc.). Second, discourse is understood as something that is expressed consciously, controlled, not something that is out of control or expressed outside of consciousness.

The second important characteristic is Context. Guy Cook (in Sobur [4]) says that discourse covers text and context. Text is all forms of language, not just words printed on sheets of paper, but also all kinds of expressions of communication, speech, music, pictures, sound effects, images, and so on. Context is all situations and things that are outside the text and affect the use of language, such as participants in the language, situations where the text is produced, the intended function, and so forth. The discourse here, then interpreted as text and context. Eriyanto [3]sees that the focus of discourse analysis is to describe the text and context together in a communication process.

Another important aspect in the analysis of critical discourse is the historical aspect which is the third characteristic. Eriyanto [3] mentioned that one important aspect to be able to understand a text is to place the discourse in a particular historical context. Understanding of the discourse of the text can only be obtained if we can provide the historical context in which the text was made, for example: the social-political situation, the atmosphere at that time. 
The fourth characteristic is Power. The power context is one of the main distinguishing features between discourse analysts and critical discourse analysis. According to Eriyanto [3] every discourse that appears in the form of text, conversation or whatever, is not seen as natural, and neutral, but is a form of power struggle. The discourse views power as a control. Eriyanto [3] and Badara [5] argue that a person or a certain group controls other people or other groups through discourse.

The last characteristic is Ideology. Critical discourse analysis examines the ideology that is hidden in the use of language. Ideology is a central study in the analysis of critical discourse. This is according to Eriyanto [3] because text, conversation, and others are forms of ideological practices or reflections of certain ideologies.

\section{Results And Discussion}

\subsection{The Need to Report}

Humans as living things have needs that must be met. By using Maslow's perspective, we will get a hierarchy of needs that need to be met, beginning with the Pshychological Needs: a basic physical biological needs of clothing, food and shelter. After the basic met, then the next is the second need in the form of Safety Needs: security and safety of the person concerned.

When a person feel something reduce his or her Safety condition, that person will do something to cope with it. Some way to coping is by ask another party that that person thing able to resolve the Safety condition problem. Lets call that another party as the Fixer. But if that person didn't know who is the Fixer, that person will call another party who in that person minds able to connect him or herself to the Fixer. Lets call this party as the Connector. That's why there is mechanism needed to connect that person to some party who able to solve his or her Safety problem, such as online system lapor.go.id as the Connector to relay that person requirement to the Fixer. After all most of people nowadays have a gadget and internet connection to do that. So we can see tha kind of report which is considered reduce their Safety such as damaged roads near their housing, clogged drains, online fraud to their card swallowed by machine. The assumption that they have a right to have full Safety plus a facilitation get their rights, encourage idea that they have right to get served. Which is sparking a kind of privilage in their reports. Both Psychological Needs and Safety Needs is in a same group called "Basic Needs" even it have different hierarchys.

How about a kind of report which is didn't directly reducing the reporter's Safety? For example, a report about some damaged road because the reporter coincidenly passing that road? That's the next human need, the Belonging Needs: a need "To Be Needed". In this condition, report something that didn't directly reduce the Reporter Safety yet still on the Reporer cirlcle of society make the Reporter fullfill a need To Be Needed: that he or she has important part to maintenance society's system. That condition will trigger the a self satisfaction of achievement to fulfill the next need: Self Esteem Needs. The fulfilling of Self Esteem Needs will make that person that Both Belonging Needs and Self Esteem Needs is in a same group called "Ego Needs" even it have different hierarchys.

The satisfaction rush that $\mathrm{s} / \mathrm{he}$ is an important part to maintenance society system will boost his/her Privilage when make a report. Which mean by Maslow point of view, we can say that there is an urge to report something to fulfill that person needs: the (half of) Basic needs 
Needed and the Ego Needs". So by borrowing some part Maslow's Hierarcys of Needs we can illustrated this kind of need in Figure 3"

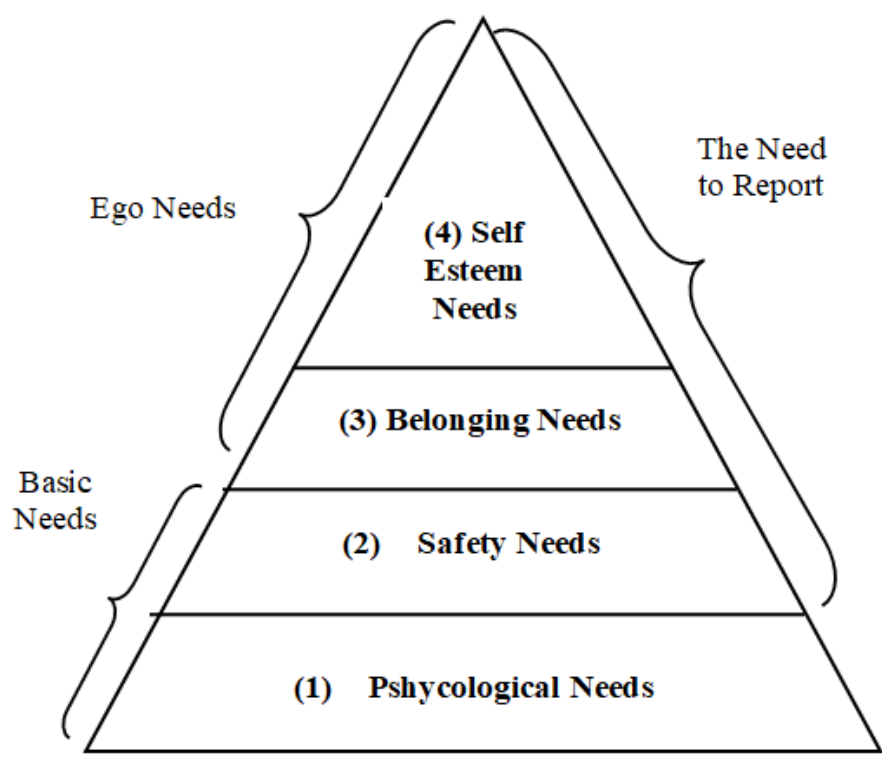

Fig 3. The Need to Report

So in Figure 1 we can say that the Need to Report will occur after that person at least fulfill the Psychological Needs. At (2) because that person Safety Needs is reduced, or threatened in some way. And then in (3) its because that person need belong to something important and finally to get some achievement to boost that person (4) Self Esteem. At some point in the progress of reporting, that person gain some spark of Privilage which is accumulated. Could be caused by that person though that s/he pay more than deserved, angry, feel important, etc. That accumulated of "privilage" influincing that person way of reporting. But can we call it deviance?

\subsection{Deviance in Reporting}

Deviant behavior is like what was explained by St. Agustine, that we know well what it is, until someone asks us [1]. This means that there are different judgments where one's behavior will be judged as deviant by a group of people, and judged not to deviate by another group. So Clinard \& Meier define deviant behavior in 4 ways. The first is based on "average" standardization, ie non-standard behavior will be considered deviant.

This method immediately causes problems because it will certainly consider all minorities as deviant behavior. To overcome this, the behavior that is considered different from the standard should not be directly assessed as deviant behavior, but as a behavior that "should" or "should not".

The second way is to violate the value of absolute norms. This concept basically assumes that the basic values of society are clear where members generally agree on what is a deviant act because the basis for acceptable behavior has been understood from the beginning. The 
problem is that the basic values of this society are usually derived from the moral values of the middle class society plus the bias values of the writers used by the middle class community: whether they are rural, traditional, or religious. As a result, behaviors that are considered "moral" sometimes become destructive.

The third way is reactivist, ie behavior is called deviant because it is successfully labeled as deviant by others. So in this way, an action will only be identified as deviating based on the reaction of the label who is a community or social control agent. The disadvantage of this method is that just because it is not labeled does not mean it does not deviate. An easy example is when someone steals, then when the behavior is not discovered, he will not be labeled as deviant behavior.

The last way is called deviant behavior when violating normative behavior. The so-called norm itself is a standard, a human condition that should or should not be thought about, said, or done in certain situations. The basic concept of the norm itself is twofold, namely the evaluation of behavior and expectations of behavior. The first is the concept of how a behavior that "should" or "shouldn't" appear in a certain situation or place. For example, not to smoke in public escalators. The second concept is the rules of behavior that originate from traditional or cultural customs. Norms themselves are not always in the form of rules, because norms are social property that is shared, while regulations can be made by individuals and forced upon others.

One of the characteristics of critical discourse analysis is an interdisciplinary perspective in describing a phenomenon. Likewise in this article. The sociological perspective provides context in the study of the anonymity of the reporting account giving an illustration that although reporting has become one of the basic needs, namely as a form of achieving a sense of security, but paradoxically, the implementation of reporting needs is still colored by fear so anonymity strategies are chosen in reporting.

In analyzing the behavior of the reporters, we can start from the display of accounts that appear on the website which is divided into two: anonymous and non-anonym accounts, that is, accounts that have names or accounts using cellphone numbers as the identity of the reporter. The word anonymous comes from the Greek anonymia, which means "no name", which describes a situation where it is unknown who the person is doing. The main function of anonymous is to protect identity, for example in elections or to do charity. In this online era, anonymous are used because they are aware of the freedom of the right to "speak" but at the same time they also have fear or shame so they choose to remain unknown. At the same time because it is free to talk, it also makes it easy for anonymous accounts to offend others without fear, or minimize the possibility, to be executed by those for whom the material is not originally mentioned.

The pattern of anonymity not only uses the anonymous features in the system, but can also be realized using a censored cell number. Anonymity in the context of online reporting is the concealment of the reporter's identity as a citizen, not as a username. Username allows a citizen to create a new identity that is able to mask his identity which is recorded administratively. 
Tabel 1. Anonymity Reporters

\begin{tabular}{|c|c|}
\hline No & Discourse Report \\
\hline 1 & $\begin{array}{l}\text { User Account : Anonim } \\
\text { Report Status \& Time } \\
\text { - Followed up by the Agency } \\
\left.\text { - Distributed to PT Pos Indonesia.(April } 11^{\text {th }}, 2019.01: 51\right) \\
\text { Contents of the report } \\
\text { Application Tracking Items : } \\
\text { Please MPC Surabaya immediately fix the flow structure! Even though this is owned by the } \\
\text { government. not private property. What it is. help please. Because the package has not } \\
\text { moved for a long time, even though it has arrived there and I have also paid. many also } \\
\text { complain that the service is very bad. thank you! }\end{array}$ \\
\hline 2 & $\begin{array}{l}\text { User Account : } \\
\text { Anonim } \\
\text { Report Status \& Time: } \\
\text { Verified } \\
\text { Contents of the report: } \\
\text { Distributed to Sukabumi Regency Public Works Department } \\
\text { Complaints about damaged roads and landslides } \\
\text { Good afternoon. I reported that the street was Jubleg, Sukabumi Regency to Parubaya, } \\
\text { Sukabumi Regency (as I know it) needs immediate repairs because the roads are already very } \\
\text { damaged. I request the regent and deputy regent regents. sukabumi to immediately carry out } \\
\text { the road repair process. along the road there was badly damaged, and there was no repair at } \\
\text { all of the landslide. It has been more than } 1 \text { year, and again at this time due to the disastrous } \\
\text { land shift in the village of Kertaangsana Nyalindung, the road was much more damaged and } \\
\text { seemed like there was no attention from the government. this report please proceed } \\
\text { immediately. Thank you }\end{array}$ \\
\hline 3 & $\begin{array}{l}\text { User Account : } \\
+628128496 x x x x \\
\text { Report Status \& Time: } \\
\text { Verified by Admin } \\
\text { Distributed to Ministry of State-Owned Enterprises. (August } 7^{\text {th }}, 2019.17: 33 \text { ) } \\
\text { Contents of the report: } \\
\text { Electricity has not been lit : } \\
\text { PLN Ciputat Tangsel!!! } \\
\text { Why did the electricity go out in the Kampong Sawah Lama, Ciputat? No further notice. } \\
\text { Please repair immediately, we are waiting. }\end{array}$ \\
\hline
\end{tabular}

Awareness that government administrative power can reduce the sense of security behind this concealment of the reporter's identity concealment. In addition, concealment of identity also implies that the reporter's discursive pressure on the contents of the report is the government's main concern. Anonymity can also be a discursive strategy to disrupt administrators by providing false reports. Normative sociology may be able to classify such things into a form of deviant behaviour. 
The emergence of these two possibilities makes anonymity a gray space: between the deliberative space of citizens to safely report deviations of public services or the space to make chaos of public services. However, this anonymity can be ensured by verifying the certainty of irregularities in public services and / or examining the evidence enclosed in reporting.

In the Hofstede Cultural Dimension, Indonesia has a high value in Power Distance which means it depends on the hierarchy, inequality of rights between holders of power and not holders of power, communication is done indirectly and negative input is hidden. Indonesia also has a low value in Uncertainty Avoidance, which is an attempt to deal with future uncertainty. Because the future is uncertain, it is overcome by efforts to maintain harmony in the workplace. For example, there is a strong tendency in Indonesia related to Javanese culture in separating internally from the external. When someone is disappointed, it is natural in Indonesia not to show emotions or anger externally. This can be assessed in a Conflict Resolution, where Direct Communication as a direct resolution is often seen as a threatening and uncomfortable situation in Indonesia so that it prioritizes third parties as intermediaries.

Another example is the phrase "As long as the Boss is Happy", which means that by making the boss (the party with a higher hierarchy) happy to make himself respected. If he is respected he will not experience status or economic uncertainty and will be valued as a valuable member of the system.

So anonymous is a natural thing when someone talks on a sensitive issue. Suppose someone has a sexual problem that has many unanswered questions, then he will choose to act as anonymous to ask the online community without disclosing his identity so as to avoid the risk of being exposed publicly. Another example is to report a sensitive issue related to where he works until he lives with the authorities, where if his identity is found to be at risk of experiencing something unpleasant like, will make someone also choose to be anonymous.

Power Distance in Indonesia can also be seen as a reason for reporting systems like this being used. Government agencies are seen as having a higher hierarchy in Indonesia. Take for example someone who uses a t-shirt, shorts and flip-flops will not have problems getting into the mall or bank, but will be questioned when going to government agencies that are used to serve the public directly. If we return to the norm, then at the time where the clothing is considered "impolite", but at the same time it means that the institution concerned is "imposing the norm" on those who "should be served". Even though it sounds paradoxical, the ability to impose the norms means the existence of a higher hierarchy so that the community served ultimately places itself in a lower hierarchy.

When there are things that are considered to have a condition of "reducing a person's Safety condition" in which those conditions are considered to be resolved by the government agency, a party that is considered to be of higher hierarchy, concerned will choose an intermediary to deliver it. Why? Because if it is delivered directly it will be considered as "negative input", which is something that is tried to be avoided as a "norm" because if it is done it will be judged "deviant". This means the existence of intermediaries such as LAPOR! it can also be seen as a path that is considered to be an equalizer in the hierarchy between parties in an effort to resolve a conflict.

These conditions over time and the increasing awareness of the community to be entitled to be served as well as increased awareness of government agencies to serve, make a change in the hierarchy: Privilage to be served which is also an effect of Self Esteem as part of the community. Privilage is what ultimately creates the norm of "politeness" in interacting to resolve conflicts, but is bridged by the website as a third party who also has an anonymous system, making reporters sometimes deviate when reporting. Do not forget because even 
anonymous does not mean that the data displayed is also correct. Such deviant behavior can be seen from the use of exclamation marks, which are signs for command sentences as an indication as a party of a higher hierarchy.

Of course, if we go back again to the condition whether it can be said "deviant behavior", will be responded to about how the perception of "deviant" itself. Because those who use exclamation marks will not feel as deviant because they feel they have a higher hierarchy. But for reporters who do not use the mark, the audience who is reading the report, so the party ordered can feel otherwise. However, one thing that is certain is that there is a change in the hierarchy that occurs between the reporting party and the reported government agency in resolving a conflict, at least in the situation of using the LAPOR! as an intermediary.

\subsection{Hierarchical Language Patterns}

The report discourse is basically an imperative discourse which means that the speaker wants the speech partner to do something in the future in accordance with the wishes of the speaker, namely to make improvements to the services performed. In addition to these characteristics, the report discourse is a discourse formed by the psychological condition of the speaker who feels that he knows the ideal situation so that the ideal condition is compared with the reality of the public service received. Such psychological conditions are rooted in the ideological position of speakers who see themselves as having certain rights that deserve the ideal conditions of public service.

The construction of the ideological position is manifested into two patterns of language use, namely the language pattern that places the reporter's position as a party higher than the government and the language pattern that negotiates the reporter's position with the government as shown in table 1. The text section in the Report Contents in bold has a marker lingual pattern of the language. The lingual marker functions to imitate the rest of the rest of the text.

Table 2. Commanding or Higher Position Discourse Report at LAPOR!

\begin{tabular}{|c|c|}
\hline No & Discourse Report \\
\hline \multirow{12}{*}{1} & User Account : \\
\hline & Febiyanda Aris \\
\hline & Report Status \& Time \\
\hline & - Verified by admin \\
\hline & - Distributed to Regional Disaster Management Agency Palangkaraya. (August 10 ${ }^{\text {th }}, 2019$. \\
\hline & $10: 23)$ \\
\hline & Contents of the report: \\
\hline & Land Burners \\
\hline & Hallo law enforcement officers, may we see the court openly in the arson of land in \\
\hline & $\begin{array}{l}\text { Palangkaraya, because until now no one has been arrested, criminals hiding behind thick smoke, } \\
\text { poisonous, life-killing, returning our rights to breathe as humans, show us where the criminals }\end{array}$ \\
\hline & are!! Don't blame the nature, the season, the rain, or maybe even later God is blamed on the \\
\hline & $\begin{array}{l}\text { basis of the disaster, because obviously these are all the results of human actions !!, } \\
\text { "palangkaraya burned 2019" }\end{array}$ \\
\hline & User Account : \\
\hline 2 & $+\underline{628586620 \times x x x}$ \\
\hline
\end{tabular}




\section{Report Status \& Time :}

- Closed by admin

- Distributed to City Transportation Department Semarang. (January 1 ${ }^{\text {st }}, 2019.08: 01$ )

\section{Contents of the report:}

$\mathrm{Jl}$ Thamrin Semarang is made in 2 directions again.

How do you want it, if Jl. Thamrin, Semarang is made 2 directions again!!! Make more traffic long and narrow!! There were two policemen on guard who couldn't unravel the traffic. Please don't try silly things!!! Thanks

\section{User Account}

Operator Sorot

Report Status \& Time:

- Closed by Admin

3 - Distributed to Department of Housing and Settlements of Semarang City. (October $4^{\text {th }} .2018$. 09:32)

\section{Contents of the report:}

The Tugu Monument was crossed out with graffiti. What the heck, sir please investigate using the cctv.

The pattern of language usage that describes the speaker puts himself in a higher position than the government is shown by the use of the phrase, what the heck and the word don't. The phrase "what the heck" denotes the denial of the reality of public service received by speakers because the reality is judged to be in accordance with ideal conditions. Denial as an action carried out with language can only be done by a speaker who thinks that the ideal conditions he believes must be realized by the speaker. The speech partner is subordinated by the speaker in the representation of the discourse. Meanwhile, the use of the word "don't" is a demonstration of the authority of a speaker because the word "don't $\mathbf{t}$ " make a report made by a speaker is a command. The preliminary condition that allows the commanding action to be carried out is that the speaker feels that he is attached to a certain authority so as to make him valid to take the commanding action.

Table 3. Polite Discourse Reports at LAPOR!.

\begin{tabular}{|c|c|}
\hline No & Discourse Report \\
\hline \multirow{12}{*}{1} & User Account \\
\hline & Mutia Sari \\
\hline & Report Status \& Time : \\
\hline & $\overline{\text { Verified }}$ \\
\hline & Distributed to Pasar Kemis Sub-District. Tangerang District. (August $2^{\text {nd }}, 2019.12: 28$ ) \\
\hline & Contents of the report: \\
\hline & $\overline{\text { Please improve service }}$ \\
\hline & The worst government service of all time is in the district of Tangerang, specifically the Pasar \\
\hline & Kemis sub-district. Please, just fire the clerk's administration officer whose name is Mr. Aji. a \\
\hline & lot of complaints about the process of making a family card experienced by residents around, \\
\hline & times my child's name is wrongUntil the publication in December 2018 was still wrong and the \\
\hline & $\begin{array}{l}\text { officer even cut my child's name to be re-tackled to make it physically appropriate and said } \\
\text { that the name would be changed directly in the database. Until the time I make a child's birth }\end{array}$ \\
\hline
\end{tabular}


certificate, my child's name is still wrong. On August 2, 2019 it turned out that my child's name in the system had not been changed! I asked other officers to take care of it but there was no response. Poor you Tangerang District government.

\section{User Account : \\ Erni Elmoo}

\section{Report Status \& Time :}

Verified

Distributed to City Transportation Agency, Tangerang. (August $6^{\text {th }}, 2019.18: 03$ )

\section{Contents of the report:}

2 Land Trucks, Minimal Lighting, Steep Road (Jl. Raya Cisauk):

Cisauk highway is very dangerous and terrible. I want to convey about Cisauk highway heading to Electric Railroad Commuter Line. Besides of traffic jam, there are lots of terrible vehicles, such as big trucks, passing by every day without knowing the time !!!! lack of lighting, steep roads, very terrible and very prone to accidents. Please for the authorities. How to make these terrible roads safe to cross? Besides terrible also very bad traffic !! For big cars, please also have certain hours and certain routes !!! There are lots of housing here and we, as citizens, are always afraid of going out of the house especially at night !! Living in this area must face fear every day. Please make it feasible to walk around our housing.

\section{User Account :}

Montana Sinuraya

\section{$\underline{\text { Report Status \& Time : }}$}

- Closed by Admin

3 - Distributed to Local water company Tirto Moedal Semarang. (Nov 16 ${ }^{\text {th }}, 2018.16: 43$ )

\section{Contents of the report:}

Please for the authorities, the water of the PDAM Dinar mas, meteseh subdistrict, Tembalang sub-district, has not been flowing for 2 days. we really need it. how does it work! water often does not work in our area. please fast response from relevant parties. thank you!

\section{User Account \\ Surya Saputra}

\section{Report Status \& Time :}

Verified

Distributed to Public Hospital dr. R. Soetrasno, Rembang.

\section{Contents of the report:}

\section{Inconveniences}

Good morning, I request permission to respond, related to health services in Rembang Regional Hospital, especially PICU Room, since when the patient's parents are prohibited from waiting for the patient? and the person in charge of the room named Mrs. Anis please give sanctions because she talks impolitely to visitors or the patient's family! she also when in the room always talk and laugh loudly, very disturbing the comfort of patients, especially children and toddlers. Thank you

The second language pattern is a pattern that accentuates politeness by using the words "please" and "ask/request" to negotiate the speakers' report followed up by the government. Courtesy is instrumented as reducing the report's imperative level. However, as mentioned earlier that the discourse of reports formed by psychological conditions is entitled to ideal conditions, the use of help and begging cannot be the basis for saying the government is still 
considered higher than the speaker as the people because public services which are an operational form of government authority are not free from interruptions. Therefore, the speaker only negotiates the report because the two parties are represented discursively in an equal relationship.

This politeness instrumentation can be related to the pattern of report anonymity. Table 1 shows that the text negotiating a report is carried out by a speaker who writes his identity in the report. The negotiations were carried out to reduce the coercive potential for his own security that the government could do. The historical context of the government in the path of Indonesian history which was once in a position free of interruption can provide an understanding that the negotiation is still influenced by trauma over the government's ability to act coercively. This is reinforced by the tendency of anonymous accounts to use language that shows their authority as citizens who are entitled to the ideal conditions of public service.

\section{Conclusions}

The discourse language pattern of the report is related to the reporting anonymity pattern on the LAPOR! Portal. The language patterns that indicate the reporting authority are used by anonymous accounts, as well as the language patterns of report discourse that only negotiate reports used by accounts that state identity in the account used. However, the pattern of interrelation, the shift in hierarchy in the psychological reality of the reporter. Reporting parties no longer see the government-people relations as patron-client. The reporter actually shows he feels in a condition he feels he has the right to be served ideally by the government. However, the trauma of the potential coercive treatment of the government that has occurred in the past makes a demonstration of the reporting authority's authority only if it is in anonymity.

\section{References}

[1] M. B. Clinard and R. F. Meier, Sociology of Deviant Behavior 6th Ed. New York: Holt, Rinehart and Winston, 1985.

[2] U. Fauzan, "Analisis Wacana Kritis Dari Model Faiclough Hingga Mills," J. PENDIDIK, pp. 123137, 2014.

[3] Eriyanto, Analisis Wacana: Pengantar Analisis Teks Media. Yogyakarta: LKiS, 2001.

[4] A. Sobur, Analisis Teks, Suatu Pengantar Untuk Analisis Wacana, Analisis. Semiotika dan Analisis Framing. Bandung: PT.Remaja Rosdakarya, 2009.

[5] A. Badara, Analisis Wacana Teori, Metode, dan Penerapanya pada Wacana Media. Jakarta: Kencana Prenada Media Group, 2012. 